\title{
The Effectiveness of the Communication Training Program for Combating Violence Against Women
}

\author{
Şener Şentürk ${ }^{*}$, Meriç Kanbur Tuncel ${ }^{2}$ \\ Faculty of Educational Sciences, Ondokuz Mayıs University of Samsun, Turkey ${ }^{1}$; Faculty \\ of Educational Sciences, Abant İzzet Baysal University of Bolu, Turkey ${ }^{2}$ \\ *Corresponding author: egitimhekimi@gmail.com
}

\begin{abstract}
Domestic violence (also named as domestic abuse, battering, or family violence) is a pattern of behaviour which involves violence or other abuse by one person against another in a domestic setting, such as in marriage or cohabitation. Domestic violence against women can be categorized as physical, sexual, psychological or economical violence. It can be seen that women exposed to such types of violence develop physical or psychological problems, even in some cases the violence ends up with domestic homicide or suicide. It is thought that an educational program which will enable these women to reconstruct their self-esteem and look to the future with hope with healing and developing skills should be prepared. Therefore, Elimination of Violence Communication Training Program was prepared and it is aimed to find the effectiveness, positive/negative conditions occurring during the application of the program or the shortcomings of the program.
\end{abstract}

In this experimental research, pre and post-test control group design was used. The duration of the application of the study was 16 sessions (48 hours). Quantitative data were gathered through "Family Evaluation Scale", which highlights the dimensions of domestic violence against women within the family; "Violence within the Family Scale", which highlights the violence experiences; "Communication Skills Evaluation Scale", which highlights the communication skills; "Life Satisfaction Scale", which scales the life experiences of the participants. In addition, the quantitative data were supported with observation forms, interview records and forms including participant opinions. The participants of the experimental group showed no meaningful relationship between their pre and post test results in terms of communication skills, whereas the sub-categories of violence within the familyverbal violence, emotional response of family functionality, and behaviour control- showed meaningful relationship in favour of post-test and it was found that the mean of pre and post test results of the experimental group showed an increase in favour of post-test in terms of all dimensions of the scale.

Keywords: Domestic violence against women, domestic violence, elimination of violence, communication training. 


\section{Introduction}

Violence against women (VAW), also known as gender-based violence, is violent acts that are committed against women just as a result of their gender. Violence against women, irrespective of gender, religion or race, is $36 \%$ and still continues today just as before in Turkey, which is a model country for the world by its recognition of the "freedom of choice and election of women" in the early days of the establishment of the republic (KSGM, 2015: p.16).

Worldwide movements struggling with violence against women began with feminist movements in the United States and Britain in the 1970s. In 1970s, some courses of action were adopted in order to prevent any kind of discrimination against women in Beijing Women's conferences held in Mexico-1975, Copenhagen-1980, Nairobi1985 and Vienna-1993. In this process, it is seen that in the USA and Europe, especially the non-governmental organizations, have set up advisory posts, shelters and action plans for violence against women. The most comprehensive legal arrangements have been made by the Law No. 6284 on " Act of Family Protection and Prevention of Violence Against Women, 2012" enacted by the General Directorate on the Status of Women in Ministry of Family and Social Policies, after the signing of the "Council of Europe Convention on the Prevention of Violence Against Women and Domestic Violence and the Struggle against them" in Istanbul2011 although legislative regulation were previously done regarding gender inequality and freedom of the person in the same periods in Turkey with the provisions of 4709, 5170 and 4320 (Resmi Gazete, 1998; Resmi Gazete, 2001). In accordance with this law, violence was defined as the physical, sexual, psychological or economic attitudes or behaviours resulting in harm or suffering as well as likely threats and oppression or limitation to freedom that might occur both in public and private sphere.

Within this process, violence prevention centres (KOZA), advisory call centre (ALO 183), family counselling centres, guest houses were established by the Ministry of Family and Social Policy. Moreover, "Psycho-social Support and Crime Intervention Units" by the Ministry of Health; "Domestic Violence Division" were established by the Ministry of Interior's Police General Directorate of Public Security Department. Within the General Command of the Gendarmerie, "Women and Child Section Supervisors", counselling centres, and shelters were opened by municipalities and NGOs. The government has tried to raise awareness by taking some precautions against violence with banners and public spots. Nevertheless, the number of the women who were killed by domestic violence was 171 in 2009, 177 in 2010, 163 in 2011, 155 in 2012 and 176 in 2013. 
It is normal for couples who have been brought up with different attitudes and behaviours and married to different expectations to cause uncomfortable expectations of family conflicts. However, if these expectations are not solved by appropriate communication channels, the communication language can be turned into violence because communication cannot be carried out in a healthy manner and possible problems cannot be solved and effective communication skills are not available (Aktaş, 2006: p.201). The woman, who is the victim of violence, feels herself inadequate and loses her self-confidence. At the end she goes into depression due to feelings of despair (Tarhan, 2014: p.187). This situation affects the relations within their families and their environment. She starts to accept the violence coming with the pressure of the environment and the result is that her marriage ends with divorce or she may be killed by her husband or mate. For this reason, it has been thought that women should be educated to develop protective and preventive behaviours by gaining awareness toward violence and to acquire skills to solve communication problems related to family and environment. It is hoped that women having effective communication and problem-solving skills by the program will be able to carry out the process more healthily through action plan. So, they will not let to give rise to violence and face a possible violence. In this direction, this study aims to reply this question: "What is the effectiveness of the training program regarding violence against women?".

\section{Methodology}

\section{Research Model}

Experimental design with pretest-posttest control groups was used in the study. During the research which examines the effectiveness of the SIMEP consisting of 16 sessions, it was aimed to explore the cause-and-effect relationships between the variables (Karasar, 2005: p.92). So, a control group was used to increase the reliability and validity of the study in the experimental designs (Kaptan, 1993: p.74).

\section{Participants of the Study}

The study group consisted of 14 women who lodged an application to the Social Service Centre Directorate or Family Counselling Centre due to violence. 14 of them constitute counselling group consisting from volunteers and participated in the trainings and 14 of them constitute the control group who stated that they could not come to the trainings for various reasons but wanted to contribute to the research. 


\section{Data Collection}

The data was acquired by Personal Information Form related to Participants, Communication Skills Evaluation Scale (IBDO) and Domestic Violence Scale for Women (AIS). The obtained data was supported by observation and interview forms.

The Communication Skills Assessment Scale (IBDO) developed by Korkut (1996) composed of 25 expressions with 5 likert types. There is no inverse item in the scale. The scale is one-dimensional and scores from never (1) to always (5) and the high scores on the scale means that individuals evaluate their communication skills positively. It was found out that the reliability coefficient of the scale was .76 ( $p$ $<.001)$ and the internal consistency coefficient was .80 ( $\mathrm{p}<.001)$ (Korkut, 1996). The internal consistency for this study was found to be .75 for the Cronbach alpha coefficient.

The Domestic Violence Scale (AIS), which determines the severity and types of violence perpetrated in the family, consists of a 30-item questionnaire developed by Çetiner (2006). The scale scores "1 for never", "5 for always" by 5-point likert type items and is found to be a five-factor structure as a result of factor analysis. It was found that the internal consistency coefficient (Cronbach alpha) of .95 and split half reliability of .91 , which explains that the $63.83 \%$ of variance of factors entitled as physical violence, emotional violence, verbal violence, economic violence and sexual violence. The Cronbach alpha coefficient for internal consistency for this study was .89.

\section{Data Analysis}

For analysing the acquired data, as the value of pre-test and post-test applications of the scales "Communication Skills Evaluation Scale", "Female Violence Scale" is $\mathrm{n}<30$, the Mann Whitney U-test and the Wilcoxon Marked Rank test were used. The qualitative data obtained from the interviews and records are included in the evaluation of frequency, percentage and content analysis.

\section{Findings}

This section contains the findings acquired from the research.

1. Findings and Comments on the Pre-test and Post-test scores of the Experimental Group

The findings of communication skills and experiences of the experimental group regarding domestic violence are given below. 


\subsection{Findings related to Communication Skills}

Is there a significant difference between Communication Skills' pre and post-test scores?

The results of the Wilcoxon signed rank test on whether there is a significant difference between the pre and post-test average scores of the women participating in the SIMEP in the survey are given in Table 1:

Table 1. Wilcoxon signed rank test results of test scores for communication skills before and after experiment

\begin{tabular}{lccccc}
\hline IBDO post-test/pre-test & $\mathrm{N}$ & $\bar{x}_{\text {sira }}$ & $\sum_{\text {sira }}$ & $\mathrm{z}$ & $\mathrm{p}$ \\
\hline Negative Order & 3 & 5.00 & 15.00 & -1.601 & .109 \\
Positive Order & 8 & 6.38 & 51.00 & & \\
Equal & 3 & & & & \\
\hline
\end{tabular}

According to Table 1, there was no statistically significant difference in terms of communication skills scores as a result of the Wilcoxon Signed Rank Test conducted to determine whether there was a significant difference between the scores of the experimental group participating in the SIMEP-IBDO after the pre-test and post-test is $=-1.601 ; \mathrm{p}>.05)$.

In the study group, it was found that the post-test points averages $(\bar{x}=3.96)$ of participants' communication skills is higher than pre-test point averages $(\bar{x}=3.76)$. Although the increase in the averages shows that the training program is effective, the reason why there are not significant relationship between some dimensions may be results from the fact that participants in experimental group stated that they have misconceptions regarding communication skills in the interviews, they couldn't exactly rate the scales because of this. However, it is observed that participants saw themselves well informed and qualified about the communication skills before the program and during the interviews and experimental process. It is seen that they do not accept this situation with the fact that they do not have enough knowledge about effective communication, effective listening, communication barriers, etc.

\subsection{Findings Related to Domestic Violence}

Is there a significant difference between pre-test and post-test scores of domestic violence? 
Table 2. Wilcoxon signed rank test results of test scores for pre- and post-test results of domestic violence

\begin{tabular}{|c|c|c|c|c|c|c|}
\hline $\begin{array}{l}\text { Post-test and Pre- } \\
\text { test Dimensions }\end{array}$ & Group & $\mathrm{N}$ & $\bar{x}_{\text {sira }}$ & $\sum_{\text {sira }}$ & $\mathrm{z}$ & $\mathrm{p}$ \\
\hline \multirow{2}{*}{$\begin{array}{l}\text { Emotional } \\
\text { Violence }\end{array}$} & Negative Order & 8 & 6,75 & 54,00 & \multirow[t]{2}{*}{-1.871} & \multirow[t]{2}{*}{.061} \\
\hline & $\begin{array}{l}\text { Positive Order } \\
\text { Equal }\end{array}$ & $\begin{array}{l}3 \\
3\end{array}$ & 4,00 & 12,00 & & \\
\hline \multirow[b]{2}{*}{ Physical Violence } & Negative Order & 8 & 7,13 & 57,00 & \multirow[t]{2}{*}{-2.85} & \multirow[t]{2}{*}{.776} \\
\hline & $\begin{array}{l}\text { Positive Order } \\
\text { Equal }\end{array}$ & $\begin{array}{l}3 \\
3 \\
\end{array}$ & 7,00 & 48,00 & & \\
\hline \multirow[b]{2}{*}{ Verbal Violence } & Negative Order & 8 & 5,94 & 47,50 & \multirow[t]{2}{*}{-2.048} & \multirow[t]{2}{*}{$.041^{*}$} \\
\hline & $\begin{array}{l}\text { Positive Order } \\
\text { Equal }\end{array}$ & $\begin{array}{l}3 \\
3 \\
\end{array}$ & 3,75 & 7,50 & & \\
\hline \multirow[b]{2}{*}{ Sexual Violence } & Negative Order & 8 & 6,30 & 31,50 & \multirow[t]{2}{*}{-1.081} & \multirow[t]{2}{*}{.280} \\
\hline & $\begin{array}{l}\text { Positive Order } \\
\text { Equal }\end{array}$ & $\begin{array}{l}3 \\
3 \\
\end{array}$ & 3,38 & 13,50 & & \\
\hline \multirow{2}{*}{$\begin{array}{l}\text { Economic } \\
\text { Violence }\end{array}$} & Negative Order & 8 & 5,13 & 20,50 & \multirow[t]{2}{*}{-.354} & \multirow[t]{2}{*}{.723} \\
\hline & $\begin{array}{l}\text { Positive Order } \\
\text { Equal }\end{array}$ & $\begin{array}{l}3 \\
3 \\
\end{array}$ & 3,88 & 15,50 & & \\
\hline
\end{tabular}

As a result of the Wilcoxon Signed Ranks Test, which was conducted to determine whether there was a significant difference between the average scores for the AIS in the experimental group participating in the SIMEP according to Table 2, negative sequences in the verbal violence subscale was found in favour of post-test $(\mathrm{z}=$ $2.048 ; \mathrm{p}=, 041<.05)$. When the rank average of AIS scores is taken into consideration, it is seen that the mean scores are higher in dimensions of negative sequences, in favour of pre-test, although there is no significant difference in other dimensions of scale. Therefore, it can be interpreted that high scores from AIS mean more exposure to violence, low end-test scores mean that the program is effective.

It was thought that participants' post-test scores regarding violence had decreased, despite the clues about the effectiveness of the program; many variables affect this case such as little number of the participants, the different attitudes of the women about the violence and the positive or negative experiences of the women before the test. However, in the qualitative data obtained from observation and interviews, it was also observed that they are less informed about basic concepts regarding violence, the legal rights and regulations in struggling with violence against women, national and international studies, effective institutions and organizations in fighting. In the case of evaluations made during the sessions, it was also seen that only the police (155) and the gendarme (156) telephone numbers are known as in case of emergency but they don't know the telephone numbers of SONIM (183) or First Aid 
(112) in case of seeing or witnessing violence. In addition, it was determined that they also don't know the centres (Social Service Centre Directorates, Provincial Directorates of Family and Social Policies, Violence Prevention and Monitoring Centres) which are active in struggling against violence and they do not have sufficient information about their existence, addresses, sanctions and support.

2. Findings related to pre-post test scores of control group.

\subsection{Findings related to Communication Skills}

Is there a significant difference between Communication Skills of pre-test scores?

Table 3. Wilcoxon signed rank test results of pretest-posttest scores for control group communication skills

\begin{tabular}{lccccc}
\hline Post-test and Pre-test & $\mathrm{N}$ & $\bar{x}_{\text {sira }}$ & $\sum_{\text {sira }}$ & $\mathrm{Z}$ & $\mathrm{p}$ \\
\hline Negative order & 6 & 8.00 & 48.00 & $-.710^{\mathrm{b}}$ & .477 \\
Positive order & 6 & 5.00 & 30.00 & & \\
Equal & 2 & & & & \\
\hline
\end{tabular}

According to Table 3, there was no statistically significant difference in terms of communication skills scores as a result of the Wilcoxon Signed Rank Test conducted to determine whether there was a significant difference between the pre and post test scores of the control group that did not participate in the SIMEP (-. 710; p> .477). In other words, the pre-test and post-test scores of the control group were close to each other.

\subsection{Findings of Domestic Violence}

Is there a significant difference between pre-test and post-test scores of domestic violence?

Table 4. Wilcoxon signed rank test results of test scores for pre-and post-treatment domestic violence in control group

\begin{tabular}{llccccc}
\hline Dimensions & Group & $\mathrm{N}$ & $\bar{x}_{\text {sira }}$ & $\sum_{\text {sira }}$ & $\mathrm{z}$ & $\mathrm{P}$ \\
\hline \multirow{2}{*}{ Emotional } & Negative order & 0 &, 00 &, 00 & -2.388 & $.017^{*}$ \\
Violence & Positive order & 7 & 4,00 & 28,00 & & \\
& Equal & 7 & & & & \\
\hline \multirow{3}{*}{ Physical } & Negative order & 3 & 3,00 & 9,00 & -.333 & .739 \\
Violence & Positive order & 3 & 4,00 & 12,00 & & \\
& Equal & 8 & & & &
\end{tabular}




\begin{tabular}{lllccrr}
\hline & Negative order & 0 &, 00 &, 00 & -2.0449 & $.014^{*}$ \\
Verbal Violence & Positive order & 6 & 3,50 & 21,00 & & \\
& Equal & 8 & & & & \\
\hline \multirow{2}{*}{ Sexual Violence } & Negative order & 0 &, 00 &, 00 & -2.646 & $.008^{*}$ \\
& Positive order & 7 & 4,00 & 28,00 & & \\
& Equal & 7 & & & & \\
\hline \multirow{2}{*}{ Economic } & Negative order & 1 & 4,00 & 4,00 & -.948 & .343 \\
Violence & Positive order & 4 & 2,75 & 11,00 & & \\
& Equal & 9 & & & & \\
\hline
\end{tabular}

$* \mathrm{p}<0,05$

Table 4. As a result of the Wilcoxon Signed Ranks Test conducted to determine whether there was a significant difference between the average scores of pre-test and post-test results of the control group that did not participate in the SIMEP emotional violence $(z=-2.388, p<.05)$, verbal violence $(z=-2.0449, p<.05)$ and sexual violence $(\mathrm{z}=-2.646, \mathrm{p}<.05)$ subscales were found to be positive based on the positive sequences, in other words, in favour of post-test as given according to Table 6.

When the rank order of AIS scores is taken into consideration, it is seen that there is not a significant difference in the other dimensions of the scale. But it is seen that the average scores are higher based on the negative sequences in subdimensions of the physical and economic violence in favour of the pre-tests. The high scores from sub dimensions mean more exposure to violence, suggesting that women may have been exposed to sexual violence because the control group included verbal and emotional violence during the pretest-posttest period. Kılıç (2012) reported that the perceptions of violence in the society have been changed recently and participants care psychological and economic violence both in Turkey and all over the World. They described physical attacks on their bodies as violence, sexual violence and sexual harassment also are thought to be accompanied physical and psychological violence but that this situation was not considered rape by women. It can be said that the external factors that cannot be taken under control cause the result of the research to come out differently.

3. Findings related to the Test Scores of Experimental and Control Group

\subsection{Findings related to Communication Skills}

Is there a significant difference between participants' Communication Skills in post test scores in the experimental and control groups? 
Table 5. Mann Whitney-U test results for independent groups of post-test scores of participants in the experiment and control group for their communication skills

\begin{tabular}{lccccc}
\hline Group & $\mathrm{N}$ & $\bar{x}_{\text {sira }}$ & $\sum_{\text {sira }}$ & $\mathrm{U}$ & $\mathrm{p}$ \\
\hline Experiment & 14 & 15.21 & 213.00 & 88.00 & .645 \\
Control & 14 & 13.79 & 193.00 & & \\
\hline
\end{tabular}

According to the values obtained in Table 5, there was no significant difference between the women who participated in the SIMEP and the women who did not participate in the Mann Whitney-U test to determine whether there was a significant difference between the average scores of the post-tests $(U=88.00, p>.645)$. However, it was seen that the participants in the experimental group have higher post-test point averages $(\bar{x}=15,21)$ than control participants $(\bar{x}=13,79)$. As stated earlier, the experimental group felt that they were competent in communication skills at the beginning of the practice, and after communication training, they stated that there were deficiencies or misinformation in many subjects. Therefore, it is thought that similar situations might be the case for the control group. It can be said that there is no significant difference between the final test scores of the communication skills of participants in the experimental and control groups and the average scores are high. 3.2. Findings of Domestic Violence

Is there a significant difference between the experimental and control groups' Domestic Violence Towards of post test scores?

Table 6. Mann Whitney-U results for independent groups of post-test scores of the participants in the experimental and control group for domestic violence

\begin{tabular}{lllllll} 
Dimension & Group & $\mathrm{N}$ & $\bar{x}_{\text {sira }}$ & $\sum_{\text {sira }}$ & $\mathrm{U}$ & $\mathrm{P}$ \\
\hline Emotional Violence & Experiment & 14 & 13.50 & 189.00 & 84.00 & .519 \\
& Control & 14 & 15.50 & 217.00 & & \\
\hline Physical Violence & Experiment & 14 & 15,79 & 221,00 & 80.00 & .405 \\
& Control & 14 & 13,21 & 185,00 & & \\
\hline Verbal Violence & Experiment & 14 & 12,96 & 181,50 & 76.50 & .315 \\
& Control & 14 & 16,04 & 224,50 & & \\
\hline Sexual Violence & Experiment & 14 & 12,82 & 179,50 & 74.50 & .272 \\
& Control & 14 & 16,18 & 226,50 & & \\
\hline Economic Violence & Experiment & 14 & 14,07 & 197,00 & 92.00 & .782 \\
& Control & 14 & 14,93 & 209,00 & & \\
\hline
\end{tabular}

According to the results of Mann Whitney-U test to determine whether there is a significant difference between the averages of the scores obtained from the AIS posttest results of the women who did not participate in the SIMEP as indicated in Table 6 , no significant difference was found. 
However, in the experimental group, participants 'mean scores of post-test scores ( $\bar{x}=15.79)$ on physical violence subscale of domestic violence in the experimental group was found to be higher than participants' the post test score averages $(\bar{x}=$ 13,21 ) in control group. As a result of the application, it is seen that the average score of women in the experimental group falls in the other types of violence except the physical violence, in other words, the severity of the violence they are exposed to decreases.

\section{Conclusion and Discussion}

The fact that there was no difference between before and after the 3 months of experiment also supported by individual home group therapies was related with the sincerity of the participants in sharing personal information in private matters. The participant K8's view on this issue supports this interpretation. During the interviews, K8 said,

\footnotetext{
"Well, I was not volunteer at the beginning. But just after the education started, because it was organized by an official institution and the features of the educators made me say "why not?". As the lessons continued well, I noticed that many things I had regarded as true were wrong. Of course, I must point out that the responses to the preimplementation surveys do not really reflect the truth, nor do I express my feelings, thoughts or experiences fully within the group and in the activities, since I am concerned about safety. I can only explain this situation in terms of the fact that the group has a certain sincerity at the end of the program, and I have the respect and trust toward the educators."
}

The participants' trust and sharing issues have also been confirmed by the family therapist who is engaged in individual therapy and practicing.

Although the data that participants' violence post-test scores decreased give some clues of the effectiveness of the program, it was thought that the low number of participants, the perception difference of women toward the violence and experiences of the participants that could occur in the positive or negative situation before the test may affect the average of the end points. However, in the qualitative data obtained from observation and interviews, it is also observed that they are not less informed or not aware of the things regarding the information about violence against women, the legal rights and regulations, national and international studies, effective institutions and organizations in fighting, whether they know what to do in 
case of violence. In the case of evaluations made during the sessions, it is seen that only the police (155) and the gendarme (156) telephone numbers are known but telephone numbers of SONIM (183) or First Aid (112) are not known by them in case of violence exposure or witness. In addition, it has been determined that they are not aware of the existence, address, sanctions and support of the application centres (Social Service Centre Directorates, Provincial Directorates of Family and Social Policies, Violence Prevention and Monitoring Centres) who are active in the fight against violence.

In the analysis of the data obtained on the interviews with women, it is said that women, who expressed that accepted the roles attributed by their spouses, their families and the society, saying that "most of their fates are pre-determined by their gender as they were born" expressed by the participant (K8), could not examine their side, and their expectations for life or they couldn't compare their similarities and differences with other women and not realize whether they are valued or not.

At the end of the program participants were asked in the open-ended questions about the effects of the SIMEP on their lives, and participants were able to express the contents covering the objectives in detail. Participants' statements regarding the effects of the SIMEP are given in Table 7.

Table 7. The views of the effects of SIMEP

\section{EXPRESSIONS}

1 The program made me notice the lack of communication in my personal life

2 The program gave me the opportunity to get to know myself better and discover my boundaries.

3 The program changed my perspective on events and people around me.

4 The program was a guide to solving my communication-related problems.

5 The program helped me rebuild my self-esteem.

6 The program helped me regain my confidence.

According to the views of the participants, the program acted as a guide to discerning and resolving communication-related problems (family and environment), especially playing a role in improving family relationships. K5 expressed this situation as, "In my relations, many issues that I regarded to have no problem in my communication have become big problems in the deeper level, many things I thought I knew were wrong". K3 expressed this situation as "During the process I realized that some of my attitudes and behaviours were faulty, so I was to improve my relationships with my family especially with my children." Participants who expressed that the program gave the opportunity to gain self-confidence, better self-awareness and to explore their borders. They also noted how important it was to break down the role given by the community that they play and how important this was for life satisfaction to 
rebuild self-esteem. K9 expressed this situation as "The program lay a bridge between "I" that I am now and "I" that I want to be." K1 expressed this situation as "Thanks to the program I get to know myself better"; K3 expressed this situation as "I learned to love myself, not to be aware and prejudiced". K14 told that "We have used expressions to recognize emotions and thoughts that we have difficulty in expressing, such as problems that we do not know how to define them, but are constantly facing in our daily lives and learn to bring different perspectives, great experiences in finding solutions to those problems ".

In the interviews, it was stated that women who expressed their satisfaction with the opportunity to express themselves and their problems demanded that training period should be much longer by stating that time duration for the sessions are short.

The main objective of SIMEP is to assist women in the program in order to create an action plan by raising awareness in their knowledge and experience of violence and to guide them in developing solutions to communication problems that may arise from themselves or their surroundings. The quantitative results of the experimental study generated and applied in this direction revealed that there was no significant difference between the pre-test and post-test results of the experimental group except some sub-dimensions of the scales in the program. However, it was observed that the mean scores of the pretest-posttest of the experimental group were changed in favour of the final test in terms of the experiences of the women of SIMEP in their family communication, life satisfaction and experience of violence. The data for these averages is shown in Table 8:

Table 8. Test group average of pre-test and post-test scores

\begin{tabular}{|c|c|c|c|}
\hline Scale & Sub dimension & Pre-test average & Post-test average \\
\hline IDO & - & 3.76 & 3.96 \\
\hline \multirow{5}{*}{ AIS } & Emotional & 2.28 & 2.05 \\
\hline & Physical & 2.32 & 2.30 \\
\hline & Verbal & 2.28 & 1.95 \\
\hline & Sexual & 2.17 & 2.08 \\
\hline & Economic & 3.09 & 2.99 \\
\hline
\end{tabular}

According to Table 8, the participants' IBDO score averages increased after the program; According to the AIS score averages, violence decreased in all subdimensions.

It is seen that communication training programs with similar contents conducted to different target populations and studies are conducted to raise awareness about violence against women exist, whereas there is no experimental research overlapping with this research topic to support the research findings. 
In the work carried out by the United Nations (2010), a program has been conducted to deal with the role of the police, who must report violence against women, report on the story of the incident and intervene the case if it is needed. The importance of national norms and standards that women should know about violence, reasons of violence, prevention of violence and cooperation between violent institutions were introduced in the training program. The reason was to enable police to improve their skills and experience to deal with such situations related with violence against women and raise their responsibility as well as their awareness.

Another work similar to this study was done within the scope of the Human Reproduction Program (HRP) supported by the World Health Organization (WHO), by the target populations covering up medical, midwifery and nursing professions. This research was based on raising the awareness of the employees working in the health sector. The aim was to raise awareness regarding issues such as history, reasons of violence, communication with the victim, guidance and support services.

Appelt, Kaselitz and Logar (2000) suggested that violence could be experienced from the first day of couples' acquaintance so, women should be conscious at an early age in terms of protection and assistance, in the European Commission on Apprenticeship Violence in Austria. In this respect, it was aimed to raise awareness of victims of violence or witnesses of violence, to provide immediate and permanent assistance and guidance were provided with those who participated in the trainees 'couples' to check up their values and attitudes. Reasons related with violence, belief patterns regarding violence, counselling services, women's shelters, myths about violence, legal rights, etc. are given as group therapy in the program in which the individual supports to prevent acts of violence. It was emphasized that all institutions should work in cooperation with each other in order to obtain an effective result in the struggle.

Allan, Todd, Coates and Richardson (2010) prepared a program with similar content with this research as a modular program designed to raise perceptions, awareness and skills of women in women's shelters. Information regarding the recent development of the shelters in the program, the roles, responsibilities, values and beliefs of women in the shelters, basic principles on violence, types of violence, types of violence, violence factors, legal arrangements related to domestic violence, communication skills and critical intervention steps in times of violence was presented in the program.

In Sweden, guidebooks have been prepared for violence against women to raise awareness levels of violence victimized women as well as violence against women. The aim was to enable them to develop their skills training based on their needs 
through professional experts, and to gain social responsibility in the struggle against violence against women (Holm, 2012).

It is observed that the current situation is described in the related institutions or nongovernmental organizations, and the contents overlap with this research topic in many countries in which violence against women is regarded as a social problem. Communication training programs have been shown to be effective in many studies with similar content made by Barry, Robb and Graham (1992), Korkut (1996) and Sarkın (2012) where experimental designs for communication education are used. However, in some studies on communication skills participants' communication skills were increased, but no significant differences were found between post-test scores of experiment and control group. Tuna (2012) found that the communication skills of the experimental group, the control group, and the placebo groups were not statistically significant as the average scores of the subjects of the experimental group were increased in the training program for high school students' anger control and communication skills. Yalçın (2010) found that the relationship satisfaction levels of the experimental group of the experimental group were found to increase in the training program after 7 sessions in the experimental study design with the pretest-posttest control group. However, even though the follow-up test performed two months later was positively related to the communication skills of them, it was observed that the effect was not permanent. Although it is predicted that participants' stimulus, motivating attitudes will affect the measurement in such studies where significant differences in pretest-posttest scores are expected in the analysis of behavioural changes and quantitative data in the analysis of participants during the training program implementation, it was thought that sufficient clarification was required for the sincere answers, especially for the special groups that require sensitivity in the pre-tests (such as the violence victim women's group). In addition to this, the demographic characteristics of women participating in the research voluntarily, their perceptions of violence, the differences in their wishes and expectations regarding past experiences or future may have affected the results of the research. It is also thought that this difference in perceptions of participants may cause differences in communication skills, the functionality of communication in intrafamilial relationships, in the expressions of violence, and to cause the expected difference in favour of the experiment group not to occur. In discussions with women participating in the training, some of the participants stated that many of the things they thought they had known regarding communication were in fact wrong, and that they later learned it in the training program, and that they were not sincere in the answers given to the pre-test because of the topics were related with their private life. However, it can be said that the training program (SIMEP) is effective by considering about what participants expressed regarding cognitive, emotional and social aspects of the process, communication and interaction process between the 
trainers, participants' social orientation adaptations, participants and the employees in the educational environment, participants' contributions to the learning process, perceptions about duties and responsibilities in the research process in which qualitative analysis methods such as observation and interview were used in order to obtain a wider viewpoint and to provide in-depth information on subjects with special cases.

In this respect, the suggestions related to the research and researchers are stated below:

1. In pre-experimental process, participants did not give much explanation for the program, which was thought to be a stimulating, motivating attitude that could affect them. However, participants shared that they did not give sincere answers in the preliminary tests, indicating that this situation affected the results of the research. Therefore, required explanations should be given to providing adequate information about pre-test practices in adult group trainings that require sensitivity.

2. Observations made during interviews with women and during training should include more cohesion activities in which women can express themselves, they are more comfortable at the point of self-disclosure, and where they actively participate in.

3. A coordinated program can be conducted to all members of the family simultaneously, by taking into account the fact that family relationships and violence resulted from different sources.

4. The program can be prolonged over a longer period of time because of the fact that it is difficult for adult people to break up the usual patterns of behaviour.

5. Considering the difficulty of creating desired behaviours, the extent to which participants in the experimental group can use the acquired skills can be reviewed in subsequent researches.

6. The Violence Communication Training Program can be conducted to the couples who apply to municipality before prenuptial contract to raise awareness of domestic violence.

\section{References}

Aktaş, A. M. (2006). Aile İçi Şiddet. Kadının ve Çocuğun Korunması. İstanbul, Elma Yayınevi.

Allan W., A., Todd, N., Coates, N. \& Richardson, C. (2010). "Supporting Northern Women - A Northwest Territories Family Violence Shelter Worker Training Program. The Department of Health and Social Services.

Appelt, B., Kaselitz, V. \& Logar, R. (2000). WAVE Training programme on violence against women. European Commission "DAPHNE Initiative. Vienna, Austria. 
Barry, E. and Robb, S. \& Graham, B. (1992). Communication skills training and patient's satisfaction. Health Communication. 4(2), 155-170.

Çetiner, Ş. G. (2006). Aile İçi Şiddet Yaşayan Kadınlarda Cinsel Sorunlar ve Intihar Olasılığı. Yayınlanmamış Yüksek Lisans Tezi, Ankara Üniversitesi Sağlık Bilimleri Enstitüsü, Ankara.

Holm, L.E. (2012). Looking the Other Way: A Study Guide to Female Victims of Violence with Disabilities. Available from: http://www.socialstyrelsen.se [Accesed 01th November 2015].

Kaptan, S. (1993). Bilimsel Araştırma ve İstatistik Teknikleri. Ankara, Tekışık Web Ofset Tesisleri.

Karasar, N. (2005). Bilimsel Araştırma Yöntemi. Ankara, Nobel Yayın Dağıtım.

Kılıç, M. (2012). Evli Çiftlerde Görülen Ruhsal Belirtiler İle Aile İşlevsellik Düzeyi Arasındaki İlişki. Yayınlanmamış Yüksek Lisans Tezi. İzmir, Dokuz Eylül Üniversitesi Eğitim Bilimleri Enstitüsü.

Korkut, F. (1996). İletişim Becerilerini değerlendirme ölçeğinin geliştirilmesi: güvenirlik ve geçerlik çalışmaları. Psikolojik Danışma ve Rehberlik Dergisi. 2 (7), 18-23.

KSGM. (2015). Kadının Statüsü Genel Müdürlüğ̈̈, Kadına Yönelik Şiddetle Mücadele Ulusal Eylem Planı 2012-2015. Ankara, Elma Teknik Basım Matbaacılık.

Resmi Gazete. (1998). 17.01.1998 tarih ve 4320 nolu Ailenin korunmasına dair kanun. Ankara, Turkey. Available from: https://www.tbmm.gov.tr/tutanaklar/ KANUNLARKARARLAR/kanuntbmmc081/kanuntbmmc081/kanuntbmmc081043 20pdf [Accesed 21th December 2015].

Resmi Gazete. (2001). 3.10.2001 tarih ve 4709 nolu, Türkiye Cumhuriyeti Anayasasının bazı maddelerinin değiştirilmesi hakkında kanun. Ankara, Turkey. Available from: http://www.resmigazete.gov.tr/eskiler/2007/05/20070504-2.htm [Accesed 21th December 2015].

Sarkın, S. Y. (2012). Çocuğa Yönelik Aile İçi Şiddetin İlköğretim 6. 7. ve 8. Sinıf Düzeyindeki Ögrrencilerin İletişim Becerileri ve Özgüven Düzeylerine Etkisi. Yayınlanmamış Yüksek Lisans Tezi. Konya, Necmettin Erbakan Üniversitesi Eğitim Bilimleri Enstitüsü.

Tarhan, N. (2014). Kadın Psikolojisi. İstanbul, Nesil Yayınları.

Tuna, D. (2012). Çözüm Odaklı Klsa Süreli Yaklaşıma Dayalı Öfke Kontrolü Eğitim Programının Lise Ögrencilerinin Öfke Kontrolü ve İletişim Becerileri Düzeylerine Etkisi. Yayınlanmamış Yüksek Lisans Tezi. İzmir, Dokuz Eylül Üniversitesi Eğitim Bilimleri Enstitüsü.

United Nations. (2010). The World's Women 2010 Trends and Statistics, United Nations, Department of Economic and Social Affairs. New York. Available from: http://www.unstats.un.org/unsd/demographic/products/Worldswomen IWW_full\%20rep ort_BW.pdf [Accesed 28th December 2015].

Yalçın, İ. (2010). İlişki Geliştirme Programının Üniversite Öğrencilerinin İlişki Doyum Düzeylerine Etkisi. Yayınlanmamış Doktora Tezi. Ankara, Hacettepe Üniversitesi Sosyal Bilimler Enstitüsü. 